\title{
SPRAY-DRIED SPIRULINA (SPIRULINA PLATENSIS) AS GROWTH PROMOTER FOR NILE TILAPIA (OREOCHROMIS NILOTICUS) UNDER LAB AND FIELD SCALE CONDITION
}

\author{
Hanan A. Abo-State ${ }^{1}$, A. M. Tahoun ${ }^{2}$ and M. L. Brown ${ }^{3}$ \\ ${ }^{1}$ Fish Nutrition Lab, Animal Production Department, National Research Centre, 33 El-Bohouth Street, \\ P.O: 12622, Dokki, Giza, Egypt. \\ ${ }^{2}$ Aquaculture Department, Faculty of Fish Resources, Suez University, Suez, Egypt. \\ ${ }^{3}$ Department of Wildlife and Fisheries Sciences, South Dakota State University, Brookings, South \\ Dakota 57007, USA.
}

(Received 15/2 / 2017, Accepted 26/ 3 / 2017)

\section{SUMMARY}

\begin{abstract}
he motivation behind this study is to determine carefully the best supplemental level of spray dried Spirulina platensis as growth promoter for Nile tilapia (Oreochromis niloticus) and its effect on their performance, feed utilization, chemical body composition and gut health. Two successive experiments were conducted (Field and Lab scale). The Field - scale was conducted with a hapa-in-pond system with diets containing four levels of Spirulina platensis $(0,0.03,0.05$ and $0.07 \%)$ to determine the best level to supplement in tilapia diet. The Lab-scale experiment consisted of four treatments diets (Control one without any supplementation and three diets comparing between the best level of Spirulina obtained from the previous experiment and two standard commercial growth promoter with standard level of each one (Probiotic or prebiotic) ( $0.2 \%$ Biogen $^{\circledR}, 0.1 \%$ Garlin Plus ${ }^{\circledR} / \mathrm{kg}$ diet ) respectively. Histological sections were collected to examine the gut health condition. The results of Field scale experiment showed that the dietary inclusion of 0.03 $\%$ Spirulina provided the best growth performance, feed utilization, and crude protein deposition than the other supplemented levels. On Lab scale side, spirulina at $0.03 \%$ conducted the same effect as commercial growth promoter (probiotic and prebiotic) in the same context, the intestine histological sections showed an increase of intestinal villi length in Nile tilapia. It could be concluded that Spirulina has a positive effect on gut conditions and that despite green water conditions contains natural cyanobacteria, the inclusion of $0.03 \%$ of spray-dried Spirulina into tilapia diet positively affected growth performance and improve gut health.
\end{abstract}

Keywords: Spirulina, growth promoter, Nile tilapia, growth performance

\section{INTRODUCTION}

Global tilapia aquaculture has been expanding at an exceptional rate during the past few decades (FAO 2016). The global production of farmed tilapia has increased from 383,654 tons in 1990 representing $4.5 \%$ of total farmed fish production to 4,507,002 tons in 2012, representing $10.2 \%$ of farmed fish production, with an average annual growth of $13.5 \%$ (FAO 2014). This rapid growth of tilapia production requires more costly input, with an increasing dependence on formulated feeds (El-Sayed, 2006). Therefore, finding novel functional feed supplements have been a major challenge facing tilapia feed industry.

Spirulina (Spirulina platensis) is microalga of the class cyanophycean. It is rich in proteins, Vitamins, essential amino acids, minerals, carotenoids and essential fatty acids (Jaime- Ceballos et al., 2006; Deng and Chow 2010). The effect of Spirulina on growth parameters has been documented for several fish species as a partial supplementation or complete replacement for protein in aqua feeds (Sultana et al., 2012andTeimouriet al., 2013a,b), as growth promoter (Abdel-Tawwab and Ahmed 2009) also provides as a source of carotenoids (Regunathan and Wesley 2006 and Teimouri et al.,2013b). Spirullina has also been used as a feed attractant (Silva-Neto et al., 2012). Further, Spirulina is used in wastewater treatment (Kamilya et al., 2006). Additionally, Spirulina has been speculated to have a positive effect on the immune system. Spirulina may potentiate the immune system leading to preventing to cancer development and viral infection (Hirahashi et al., 2002 and Ibrahim and Ibrahim; 2014). 


\section{Abo-State et al.}

Different forms of Spirulina, fresh or dried have been used as a supplement in animal's diets. Spirulina preparation and drying methods greatly affect its nutritional value. The spray dried method is the common method of producing Spirulina. Lin., (1985) found that bacterial and chemical content of spray and freeze dried Spirulina were found to be superior to conventional drying methods.

Despite previous results of many trials using dietary Spirulina in feed rations of many animal species that showed improving productivity, health, and product quality, their findings are contradictory. Subsequently, more investigation is required to assess Spirulina potentials because of its inconclusive results as an animal feed supplement (Holman and Malau-Aduli 2013)

Primary objectives of this study were to investigate the effect of supplementing tilapia diet with spray-dried Spirulina (Spirulina platensis) as growth promoter. Two successive experiments were conducted (Field and Lab scale). The field scale experiment conducted to investigate the optimum level of Spirulina platensis to be supplemented in tilapia diet as growth promoter. The lab scale experiment compare among the best level of Spirulina determined from field experiment and two commercial growth promoter (probiotic, prebiotic) and study to what extent it may affect tilapia performance and gut health.

\section{MATERIALS AND METHODS}

\section{Experimental diets}

Spray-dried Spirulina were obtained from a commercial company (IGV Food tech, Germany). The composition and chemical analysis of basal diet is given in Table (1). The dietary ingredients were finely ground, weighed, blended and pelleted using a meat mincer. Diets were dried in the oven at $60{ }^{\circ} \mathrm{C}$ for 24 hours, and crushed for adjusting feed particle size and stored at $-4^{\circ} \mathrm{C}$.

Table (1): Composition and chemical analysis of the basal diet used in the experiment.

\begin{tabular}{|c|c|}
\hline Ingredient & $\%$ \\
\hline Wheat tag & 30 \\
\hline Soya bean meal & 20 \\
\hline Fish meal & 20 \\
\hline Glutein meal & 15 \\
\hline Corn grain & 4 \\
\hline Corn oil & 4 \\
\hline Di-ca-phosphate & 2 \\
\hline Vitamins \& minerals Premix ${ }^{1}$ & 3 \\
\hline $\mathrm{CaCO}_{3}$ & 2 \\
\hline Total & 100 \\
\hline \multicolumn{2}{|l|}{ Chemical analysis \% } \\
\hline Dry Matter & 90.07 \\
\hline Crude protein & 35.00 \\
\hline Ether Extract & 8.00 \\
\hline Total carbohydrates & 36.07 \\
\hline Ash & 8.00 \\
\hline Gross energy $\mathrm{Kcal} / \mathrm{Kg}$ diet & 4356 \\
\hline $\begin{array}{l}{ }^{1} \text { Contains }\left(\mathrm{Kg}^{-1}\right) \text { : vitamin } A, 3,333 \text {, } \\
B_{1}, 333.3 \mathrm{mg} \text {; vitamin } B_{2}, 1,667 \mathrm{~m} \\
3,333.3 \mathrm{mg} ; \text { folicacid, } 333.3 \mathrm{mg} ; \mathrm{b} \\
1,333 \mathrm{mg} \text {; cobalt, } 33.3 \mathrm{mg} ; \text { seleniu }\end{array}$ & $\begin{array}{l}\text { mg; vitamin } K, 333 \mathrm{mg} ; \text { vitamin } \\
\text {, 10,000 mg; pantothenicacid, } \\
\text { anganese, 20,000 mg; copper, } \\
\text { ate, } 1,000 \mathrm{mg} .\end{array}$ \\
\hline
\end{tabular}

\section{Field-scale experiment}

This experiment lasted for 92 days in 12 hapas $\left(2 \mathrm{~m}^{3}\right)$ with 0.5 meters deep in the pond water. The experimental hapas were suspended in an earthen pond $70 \times 30 \mathrm{~m}\left(2100 \mathrm{~m}^{2}\right)$ at a commercial farm of mono-sex tilapia located in Kafer El-Sheikh Governorate, Egypt. They were supplied with brackish water (2500 ppm) under the condition of hapa - in- pond system.

Mono-sex Nile tilapia fry of $0.25 \mathrm{~g}$ weight were distributed randomly to the twelve experimental hapas at fixed total stocking density of $100 \mathrm{fish} /$ hapa (equivalent to $50 \mathrm{fish} / \mathrm{m}^{3}$ ). The twelve hapas were divided to provide three hapas (replicates) for the control group fed basal diet and three hapas (replicates) for each diet supplemented with different levels of Spirulina $(0.03,0.05$, and $0.07 \%)$. 
The four groups of fish were manually fed. The feeding rate was 10\% (30 days), $8 \%$ (30 days), and 5\% (32 days) of their live body weight per day, divided into four feeding times at 9:00 am, 12:00 pm, 2:00 pm, and 4:00 pm. Every two weeks fish from each hapa were sampled and weighed to the determined average weight of fish and the ration was adjusted according to the new weight.

\section{Water Quality}

Daily water temperature and dissolved oxygen (DO) readings were recorded throughout the duration of the study at 6.00 am and $2.00 \mathrm{pm}$ using water proof DO meter (Model HI 9146-04, Hanna Instrument Co.), while water $\mathrm{pH}$ was measured weekly at 2:00 pm using digital $\mathrm{pH}$ meter, Water alkalinity and total ammonia nitrogen (TAN mg/ L) were determined biweekly (Hanna Instrument test kits Co.). Water salinity (mg/L) was determined using a digital conductivity meter (model 4075, Jenway). The experimental water criteria were determined according to APHA (1999) Table (2).

\section{Lab-scale experiment}

A total of 300 mono sex Nile Tilapia (Oreochromis niloticus) fingerlings were obtained from a private tilapia hatchery (Kafr El-Sheikh, Egypt). Fish had an average initial weight of $2.8 \mathrm{~g}$ were held in two glass aquaria with water capacity of $90 \mathrm{~L}$ for two weeks acclimatization. Experiments were carried out in 12 experimental glass aquaria each with a water volume of 40 liters.

The experiment consisted of four treatments in triplicate the control one with no supplementation and three treatments to compare the best level of Spirulina determined from Field experiment $(0.03 \%)$ in the presence of dietary supplementation with two commercial growth promoter in their recommended level probiotic or prebiotic $\left(2 \mathrm{gBiogen}{ }^{\circledR}, 1 \mathrm{gGarlin}\right.$ Plus ${ }^{\circledR} / \mathrm{kg}$ diet $)$ respectively. Each replicate contained 20 fry. Fish were fed at $5 \%$ of their body weight for two weeks then reduced to $3 \%$. Feed were delivered twice daily at 9 am and $3 \mathrm{pm}$. The experiment lasted for 77 days, where fish were weighed every fourteen days and feed amounts were adjusted accordingly. Water temperature ranged between 25 and $27{ }^{\circ} \mathrm{C}$ while, the $\mathrm{pH}$ value was 7.5 supporting the alkalinity needed for tilapia. Aquaria were supplemented with air pump.

\section{Histological sections}

At the end of the lab-scale feeding trail, to examine the effect of Spirulina on gut health, Histological sections from different organs (Intestine, Liver, and kidney) of Nile tilapia were collected and frozen for examination in the histology lab (Faculty of Veterinary, Cairo University) The sections were fixed in $10 \%$ neutral buffer formalin, processed by paraffin embedding method and stained with Hematoxylin and Eosin stain (Bancroft et al., 1996).

\section{Chemical analysis of diets and fish}

Samples of ingredients, diets, and fish were taken at the beginning and end of the experiments and were analyzed for moisture, crude protein ( $\mathrm{N}$ x 6.25) lipid and ash content was analyzed according to AOAC (2006).

At the end of both field and lab scale experiments the growth performance parameters, feed utilization, and chemical body composition analysis were determined.

\section{Statistical analysis}

Statistical package SPSS version 16 (2007) was used for conducting statistical analyze. Means for significant differences were tested using Duncan's Multiple Range test (1955).

\section{RESULTS AND DISCUSSION}

The average values of water quality parameters measured throughout the experimental period are summarized in Table (2). Concerning the parameters measured, it was noted that, all values of ponds were closely suitable for the normal growth of warm water fish. These results are in agreement with those reported by Tahoun (2007).

\section{Field scale experiment}

Average values of Initial Weight (IW), Final Weight (FW), Weight Gain (WG), Average Daily Gain (ADG), Specific Growth Rate (SGR) and Survival Rate (SR) of Nile tilapia fry fed diets supplemented with different supplemental levels of Spirulina as growth promoter at levels $(0 \%, 0.03 \%, 0.05 \%$ and $0.07 \%$ ) are illustrated in Table (3). The initial weight was similar in all treatments group with no 


\section{Abo-State et al.}

significant differences $(p>0.05)$. Interestingly, there were significant differences $(p<0.05)$ among all treatments in all growth performance parameters declared superiority of the treatment supplemented with Spirulina at $0.03 \%$ in final weight, WG, ADG and SGR $(44.56 \mathrm{~g}, 44.31 \mathrm{~g}, 0.48 \mathrm{~g}$ and 5.62) respectively compared with the other treatments followed by control and $0.05 \%$, the worst treatment was noticed in group fed on high level of supplementation $0.07 \%$ an all pervious growth parameters $(39.43 \mathrm{~g}, 39.18 \mathrm{~g}$, $0.43 \mathrm{~g}$, and 5.48) respectively. Additionally, there was no significant difference noticed in survival rate in all treatments.

Table (2): Water quality criteria of the pond's water (Field scale).

\begin{tabular}{|c|c|c|c|c|c|c|}
\hline \multirow{2}{*}{ Month } & \multirow{2}{*}{ Temp. $\left({ }^{\circ} \mathrm{C}\right)$} & \multirow[t]{2}{*}{$\mathrm{pH}$} & \multicolumn{2}{|c|}{ Dissolved oxygen } & \multirow{2}{*}{$\begin{array}{l}\mathrm{TAN}^{1} \\
(\mathrm{mg} / \mathrm{L})\end{array}$} & \multirow{2}{*}{$\begin{array}{c}\text { Total Alkalinity }^{2} \\
(\mathrm{mg} / \mathrm{L})\end{array}$} \\
\hline & & & $\mathrm{am}$ & $\mathrm{pm}$ & & \\
\hline August & 28.9 & 7.95 & 2.3 & 6.50 & 0.18 & 169.0 \\
\hline September, & 27.4 & 7.80 & 2.5 & 6.70 & 0.17 & 187.0 \\
\hline October, & 25.1 & 7.90 & 2.7 & 6.90 & 0.16 & 165.0 \\
\hline November, & 24.7 & 7.65 & 2.4 & 6.50 & 0.15 & 145.0 \\
\hline
\end{tabular}

${ }^{1}$ Where TAN means (total ammonia nitrogen).

${ }^{2}$ Expresed as $\mathrm{CaCO}_{3}(\mathrm{mg} / \mathrm{L})$.

Table (3): Effect of different levels of spray dried Spirulinaon growth performance and survival rates (Field scale).

\begin{tabular}{lcccccc}
\hline Treatments & $\begin{array}{c}\text { initial weight } \\
(\mathrm{g})\end{array}$ & $\begin{array}{c}\text { Final weight } \\
(\mathrm{g})\end{array}$ & $\begin{array}{c}\text { Weight gain } \\
(\mathrm{g})\end{array}$ & $\begin{array}{c}\text { Average } \\
\text { daily gain } \\
\text { g/day })\end{array}$ & $\begin{array}{c}\text { Specific } \\
\text { growth rate }^{2}\end{array}$ & $\begin{array}{c}\text { Survival } \\
\text { Rate } \%\end{array}$ \\
\hline Control & $0.25 \pm 0.003$ & $41.12^{\mathrm{b}} \pm 0.325$ & $40.86^{\mathrm{b}} \pm 0.326$ & $0.44^{\mathrm{b}} \pm 0.003$ & $5.53^{\mathrm{b}} \pm 0.007$ & $98 \pm 0.882$ \\
$0.03 \%$ & $0.25 \pm 0.003$ & $44.56^{\mathrm{a}} \pm 0.795$ & $44.31^{\mathrm{a}} \pm 0.798$ & $0.48^{\mathrm{a}} \pm 0.010$ & $5.62^{\mathrm{a}} \pm 0.024$ & $99 \pm 0.333$ \\
$0.05 \%$ & $0.25 \pm 0.00$ & $40.50^{\mathrm{bc}} \pm 0.158$ & $40.24^{\mathrm{bc}} \pm 0.159$ & $0.44^{\mathrm{b}} \pm 0.000$ & $5.52^{\mathrm{bc}} \pm 0.007$ & $99 \pm 0.577$ \\
$0.07 \%$ & $0.25 \pm 0.003$ & $39.43^{\mathrm{c}} \pm 0.072$ & $39.18^{\mathrm{c}^{\circ} \pm 0.072}$ & $0.43^{\mathrm{b}} \pm 0.003$ & $5.48^{\mathrm{c}} \pm 0.000$ & $99 \pm 0.333$ \\
\hline
\end{tabular}

Means followed by different letters in each column are significantly $(P<0.05)$ different

${ }^{1}$ Weight gain $(W G)=$ final weight - initial weight .

${ }^{2}$ Specific growth rate $(S G R)=100(\ln W 2-\ln W 1) / T$

Where $W 1$ and $W 2$ are the initial and final weight, respectively, In represent Natural logarithm and $T$ is the number of days in the feeding period.

Feed utilization parameters expressed as Feed intake (FI), Feed conversion rate (FCR), Protein efficiency ratio (PER), Protein productive value (PPV) and Energy utilization (EU) were illustrated in Table (4). The results clearly demonstrated enhancement in (FCR) significantly $(\mathrm{p}<0.05)$ in treatment supplemented with $0.03 \%$ Spirulina with best FCR values (1.68) compared with the other supplemented levels although group $0.03 \%$ recorded the lowest feed intake $(74.26 \mathrm{~g})$ which reflected on enhancement on the pervious growth performance parameters.

Table (4): Effect of different levels of spray dried Spirulina on feed utilization parameters of Nile tilapia (Field scale).

\begin{tabular}{lccccc}
\hline Treatments & $\begin{array}{c}\text { Feed intake } \\
(\mathrm{g})\end{array}$ & $\begin{array}{c}\text { Feed conversion } \\
\text { ratio }^{3}\end{array}$ & $\begin{array}{c}\text { Protein efficiency } \\
\text { ratio }^{4}\end{array}$ & $\begin{array}{c}\text { Protein productive } \\
\text { value }(\%)^{5}\end{array}$ & $\begin{array}{c}\text { Energy } \\
\text { utilization }(\%)^{6}\end{array}$ \\
\hline Control & $77.06^{6 \mathrm{~b}} \pm 0.582$ & $1.88^{\mathrm{b}} \pm 0.027$ & $1.51^{\mathrm{b}} \pm 0.024$ & $33.05^{\mathrm{b}} \pm 0.785$ & $21.17^{\mathrm{b}} \pm 0.631$ \\
$0.03 \%$ & $74.26^{\mathrm{b}} \pm 1.733$ & $1.68^{\mathrm{a}} \pm 0.064$ & $1.71^{\mathrm{a}} \pm 0.067$ & $39.12^{\mathrm{a}} \pm 2.008$ & $24.91^{\mathrm{a}} \pm 1.299$ \\
$0.05 \%$ & $77.95^{\mathrm{a}} \pm 0.522$ & $1.94^{\mathrm{b}} \pm 0.006$ & $1.47^{\mathrm{b}} \pm 0.003$ & $32.57^{\mathrm{b}} \pm 0.448$ & $20.71^{\mathrm{b}} \pm 0.233$ \\
$0.07 \%$ & $78.00^{\mathrm{a}} \pm 0.322$ & $1.99^{\mathrm{b}} \pm 0.006$ & $1.44^{\mathrm{b}} \pm 0.003$ & $31.89^{\mathrm{b}} \pm 0.393$ & $20.05^{\mathrm{b}} \pm 0.238$ \\
\hline
\end{tabular}

${ }^{3}$ Feed conversion ratio $(F C R)=$ dry feed intake $(g) /$ fish live weight gain $(g)$.

${ }^{4}$ Protein efficiency ratio $(P E R)=100$ (weight gain $(g) /$ protein intake $(g)$

${ }^{5}$ Protein productive value $(P P V)=100($ protein gain $(g) /$ protein fed $(g))$. 
${ }^{6}$ Energy Retention $(E R)=$ Retained energy in carcass $($ Kcal $) /$ energy intake $($ Kcal $) \times 100$.

Results indicated significant differences $(\mathrm{p}<0.05)$ in PER, PPV and EU among fish groups. The results showed superiority of the group supplemented with $0.03 \%$ Spirulina at all the pervious parameters $(1.71,39.12$ and $24.91 \%)$ respectively than the other groups which not significantly differ among each other $(\mathrm{p}>0.05)$ in the utilization parameters.

Results of body composition of Nile tilapia are illustrated in Table (5). No significant differences $(p<0.05)$ was noticed among all treatments in Dry matter $(D M)$, Ether extract $(E E)$ or Ash content. On the other hand, there were significant differences $(\mathrm{p}<0.05)$ among treatments in Crude protein $(\mathrm{CP})$ indicating that the highest protein content found in treatment supplemented with $0.03 \%$ Spirulina $(69.63 \%)$. However, no significant differences noticed among the other treatments in CP content (control,0.05 and $0.07 \%$ ) Spirulina.

Results of the field scale declared that the best level supplemented in Tilapia diet is $0.03 \%$ spray dried Spirulina as growth promoter than the other supplemented levels $(0,0.05$ and $0.07 \%)$ in growth performance, feed utilization and body composition.

Table (5): Effect of different levels of spray dried Spirulina on body composition of Nile tilapia (Field scale).

\begin{tabular}{lcccc}
\hline \multirow{2}{*}{ Treatments } & \multirow{2}{*}{ Dry matter } & \multicolumn{3}{c}{$\%$ on dry matter basis } \\
\cline { 2 - 5 } & & Crude protein & Ether extract & Ash \\
\hline Control & $31.72 \pm 0.194$ & $68.47^{\mathrm{b}} \pm 0.260$ & $15.63 \pm 0.467$ & $13.20 \pm 0.351$ \\
$0.03 \%$ & $32.28 \pm 0.322$ & $69.63^{\mathrm{a}} \pm 0.318$ & $16.40 \pm 0.231$ & $13.40 \pm 0.115$ \\
$0.05 \%$ & $31.96 \pm 0.345$ & $67.83^{\mathrm{b}} \pm 0.441$ & $15.90 \pm 0.058$ & $13.33 \pm 0.088$ \\
$0.07 \%$ & $32.03 \pm 0.186$ & $68.10^{\mathrm{b}} \pm 0.305$ & $15.30 \pm 0.416$ & $13.50 \pm 0.379$ \\
\hline
\end{tabular}

Means followed by different letters in each column are significantly $(P<0.05)$ different.

\section{Lab scale experiment}

Average values of initial weight(IW), final weight(FW), Average weight gain(WG), Average daily gain(ADG), Specific growth rate(SGR) and Survival rate(SR) of Nile tilapia fingerlings fed diets supplemented with best level of Spirulina determined from the previous experiment (Field scale) $0.03 \%$ and two commercial growth promoters probiotic $\left(\right.$ Biogen $\left.^{\circledR}\right)$, Prebiotic $\left(\right.$ Garlin Plus $\left.{ }^{\circledR}\right)$ are illustrated in Table (6). The initial weight was nearly similar in all treatments group with no significant differences $(\mathrm{p}>0.05)$. The results declared superiority of Spirulina $0.03 \%$, probiotic and prebiotic than the control treatment $(\mathrm{p}<0.05)$ in all growth performance parameters. And declared no significant differences among these three treatments $(0.03 \%$ Spirulina, probiotic or prebiotic). The highest survival rate (SR) noticed in treatment $0.03 \%$ Spirulina $(99 \%)$, followed by probiotic $(97 \%)$ with no significant difference, then prebiotic (95\%), the lowest SR was reordered in the control (92\%).

Table (6): Effect of different levels of spray dried Spirullina, probiotic and prebiotic on growth performance and survival rates of Nile tilapia (Lab scale).

\begin{tabular}{|c|c|c|c|c|c|c|}
\hline Treatment & $\begin{array}{l}\text { Initial } \\
\text { weight } \\
(\mathrm{g})\end{array}$ & $\begin{array}{l}\text { Final } \\
\text { weight } \\
(\mathrm{g})\end{array}$ & $\begin{array}{c}\text { Average } \\
\text { weight } \\
\text { gain }(g)\end{array}$ & $\begin{array}{l}\text { Average } \\
\text { daily gain } \\
\text { (g/ day) }\end{array}$ & $\begin{array}{c}\text { Specific } \\
\text { growth rate } \\
(\%)\end{array}$ & $\begin{array}{c}\text { Survival } \\
\text { rate } \\
(\%)\end{array}$ \\
\hline Control & $2.73 \pm 0.02$ & $11.43^{b} \pm 0.36$ & $8.69^{b} \pm 0.38$ & $0.11^{\mathrm{b}} \pm 0.020$ & $3.04^{b} \pm 0.05$ & $92.00^{\mathrm{c}} \pm 2.45$ \\
\hline $0.03 \%$ (Spirulina) & $2.62 \pm 0.18$ & $13.92^{\mathrm{a}} \pm 0.49$ & $11.30^{\mathrm{a}} \pm 0.58$ & $0.15^{\mathrm{a}} \pm 0.015$ & $3.32^{\mathrm{a}} \pm 0.05$ & $99.00^{\mathrm{a}} \pm 1.67$ \\
\hline Probiotic & $2.78 \pm 0.02$ & $13.94^{\mathrm{a}} \pm 0.69$ & $11.15^{\mathrm{a}} \pm 0.68$ & $0.14^{\mathrm{a}} \pm 0.009$ & $3.32^{\mathrm{a}} \pm 0.07$ & $97.00^{\mathrm{ab}} \pm 1.67$ \\
\hline Prebiotic & $2.77 \pm 0.03$ & $13.11^{\mathrm{a}} \pm 0.19$ & $10.34^{\mathrm{a}} \pm 0.22$ & $0.13^{\mathrm{a}} \pm 0.000$ & $3.24^{\mathrm{a}} \pm 0.02$ & $95.00^{\mathrm{b}} \pm 2.5$ \\
\hline
\end{tabular}

Feed utilization parameters expressed as Feed intake (FI), Feed conversion ratio(FCR), Protein efficiency ratio (PER), Protein productive value (PPV) and Energy utilization (EU) were illustrated in Table (7).Meanwhile, the lowest feed intake recorded for $0.03 \%$ Spirulina $(24.45 \mathrm{~g}$ ) but it have the best FCR (2.18) followed by probiotic (2.25) and prebiotic (2.44) with no significant differences $(\mathrm{p}>0.05)$ which reflected with improvement in growth performance parameters declared previously in the previous 
table mention to superiority of the treatments supplemented with Spirulina, probiotic, prebiotic than the control one . Similarly, the same trend was observed in the other feed utilization parameters PER, PPV and Energy utilization.

Table (7): Effect of different levels of spray dried Spirullina, Probiotic and Prebiotic on protein and feed utilization of Nile tilapia (Lab scale).

\begin{tabular}{lcllll}
\hline Treatment & $\begin{array}{c}\text { Feed Intake } \\
(\mathrm{g})\end{array}$ & $\begin{array}{c}\text { Feed conversion } \\
\text { ratio }\end{array}$ & $\begin{array}{c}\text { Protein } \\
\text { efficiency ratio }\end{array}$ & $\begin{array}{c}\text { Protein productive } \\
\text { value }(\%)\end{array}$ & $\begin{array}{c}\text { Energy utilization } \\
(\%)\end{array}$ \\
\hline Control & $22.92^{\mathrm{d}} \pm 0.01$ & $2.65^{\mathrm{a}} \pm 0.12$ & $1.08^{\mathrm{b}} \pm 0.05$ & $23.71^{\mathrm{b}} \pm 0.85$ & $17.49^{\mathrm{b}} \pm 0.62$ \\
$0.03 \%$ Spirulina & $24.45^{\mathrm{c}} \pm 0.06$ & $2.18^{\mathrm{b}} \pm 0.12$ & $1.32^{\mathrm{a}} \pm 0.07$ & $28.60^{\mathrm{a}} \pm 1.19$ & $20.75^{\mathrm{a}} \pm 0.87$ \\
Probiotic & $24.91^{\mathrm{b}} \pm 0.01$ & $2.25^{\mathrm{b}} \pm 0.13$ & $1.28^{\mathrm{ab}} \pm 0.08$ & $30.16^{\mathrm{a}} \pm 1.62$ & $21.39^{\mathrm{a}} \pm 1.16$ \\
Prebiotic & $25.18^{\mathrm{a}} \pm 0.02$ & $2.44^{\mathrm{ab}} \pm 0.06$ & $1.17^{\mathrm{ab}} \pm 0.03$ & $26.60^{\mathrm{ab}} \pm 0.48$ & $19.08^{\mathrm{ab}} \pm 0.34$ \\
\hline
\end{tabular}

Means followed by different letters in each column are significantly $(P<0.05)$ different

The data of body composition are given in Table (8). Spirulina incorporation in tilapia diet did not affect body composition except for protein content, where the best value was recognized for fish fed on probiotic $65.50 \%$ without a significant difference with fish fed prebiotic(64.75) or Spirulina (62.45) while the lowest value $(\mathrm{p}<0.05)$ was recorded for the control at $(61.52)$.

Table (8): Effect of different levels of spray dried Spirulina, Probiotic and Prebiotic on body composition of Nile tilapia (Lab scale).

\begin{tabular}{lcccc}
\hline \multirow{2}{*}{ Treatments } & \multirow{2}{*}{ Dry matter } & \multicolumn{3}{c}{ \% on dry matter basis } \\
\cline { 2 - 5 } & $30.49 \pm 0.865$ & $61.52^{\mathrm{b}} \pm 2.050$ & $23.06 \pm 0.630$ & $11.88 \pm 0.365$ \\
Control & $30.81 \pm 1.160$ & $62.45^{\mathrm{ab}} \pm 1.260$ & $22.48 \pm 0.025$ & $11.98 \pm 0.395$ \\
$0.03 \%$ Spirulina & $31.50 \pm 0.229$ & $65.50^{\mathrm{a}} \pm 0.764$ & $22.30 \pm 0.534$ & $12.13 \pm 0.186$ \\
Probiotic & $30.50 \pm 1.500$ & $64.75^{\mathrm{ab}} \pm 0.250$ & $22.68 \pm 0.070$ & $11.55 \pm 0.050$ \\
Prebiotic & &
\end{tabular}

Means followed by different letters in each column are significantly $(P<0.05)$ different

Based on histological sections, control group showed normal villi height Fig.(1), and indicated no abnormality in intestine and liver sections, except for kidney sector that showed hemorrhage in intestinal tissue and hydropic degeneration in the epithelial lining the renal tubules Fig.(2,3). Fish fed on $0.03 \%$ and probiotic showed an increase in villi length Fig. (4, 5) Liver and Kidney sections for fish fed on Spirulina showed abnormality in the form of hemorrhages, necrosis and granuloma Fig. $(6,7)$.Histological sectors confirm the beneficial effect of Spirulina on the gut condition where intestine of fish fed on Spirulina indicated an increase in villi height.

Results from two experiment showed that the best supplemented level of Spirulina platensis as growth promoter was $0.03 \%$ which affect positively on Tilapia performance and gut health, this effect not differ than the effect of other known commercial growth promoters(probiotic and prebiotic).

Our results are in agreements with the results of (Abdel-Tawwab and Ahmed 2009) they suggested the positive effect of Spirulina as a growth promoter in Tilapia diet although they examined higher dietary inclusion than our diets they found that the optimum growth and feed utilization for Nile tilapia were obtained when fed on $0.5 \%$ live Spirulina. This differences between our results may be due to the type of Spirulina used (Arthrospira platensis) and our species. Additionally the difference in the nature of Spirulina used (live and spray dried).

Ekpo and Bender (1989) found that tilapia digest blue green algae more efficiently than Silver carp, which are strict phytoplankton feeders. They reported that the protein apparent digestible coefficient (ADC) in tilapia varied between 90.0 and $94.5 \%$ in diets with Spirulina sp. The capacity to digest microalgae protein may be due to the low $\mathrm{pH}$ in herbivorous fish stomach, which allows them to leach nutrients from the cell without breaking its cell wall (Horn and Messer 1992). This process would be very efficient for Nile tilapia considering that its stomach has the lowest $\mathrm{pH}$ level reported for a fish species, with values close to one (Ekpo and Bender 1989). In the same trend, Sarker et al., (2016) found that the improved digestibility of crude protein and most essential amino acids of Spirulina sp. suggests that this microalgae is a good candidate as an alternative protein source in tilapia feed. The same was suggested by (Abdel-Tawwab and Ahmed, 2009), where different Spirulina levels positively affected protein content of tilapia body composition but no significant difference was observed for dry matter or ash content. 


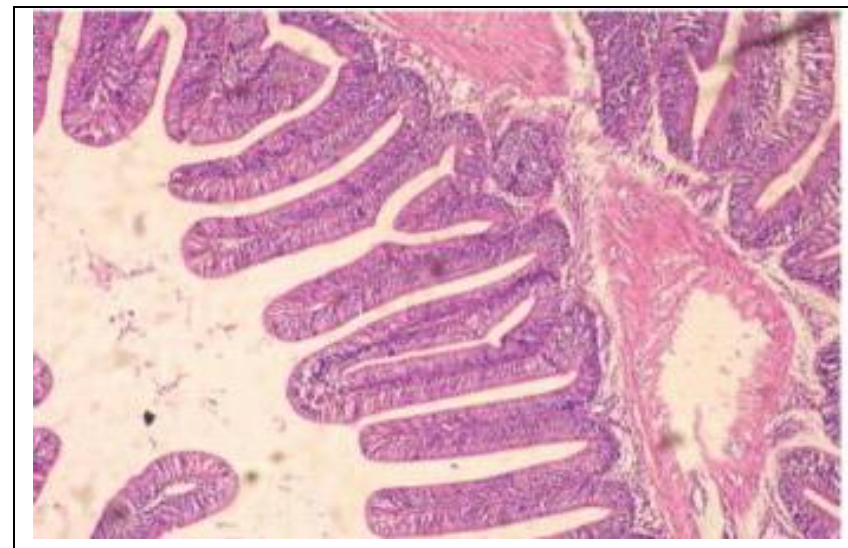

Fig. (1) Intestine of fish in control group showing normal structure and height of villi. H\&EX100.

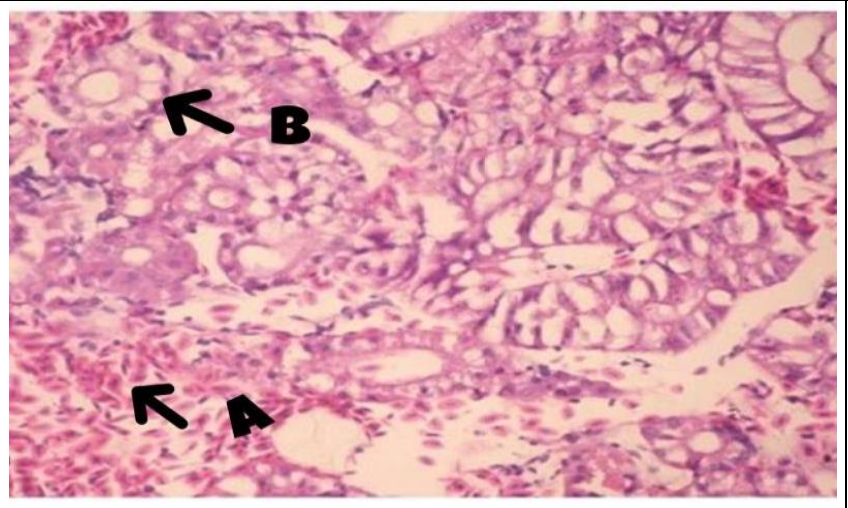

Fig. (3) Kidney of fish in control group showing (A) hemorrhage in interstitial tissue and (B) hydropic degeneration in the epithelial lining the renal tubules. H\&EX 400.

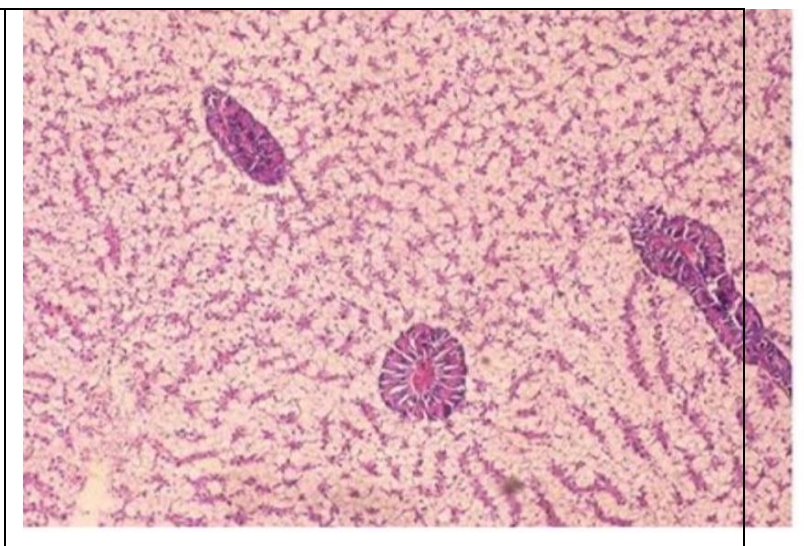

Fig. (2) Liver of fish in control group showing normal histological appearance.

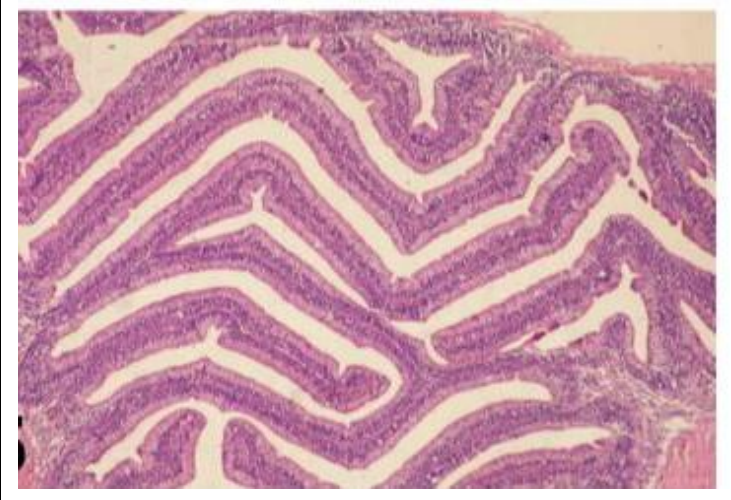

Fig. (4) Intestine of fish treated with $0.03 \%$ of Spirulina showing increase in length of intestinal villi. H\&EX 100 .

In contrast with our observation, carp fed different diets with the elevated level of Spirulina showed no difference in protein content (Nandeesha et al., 1998). Improvement in carcass protein content could be explained by the gut histology, where the intestinal section of fish fed on Spirulina showed an increase in villi length compared to control diet. Improving the gut condition may lead to more effective absorption of protein.

Obviously the improvement in growth performance, feed utilization and protein content on the fish fed diet $0.03 \%$ Spirulina have approximately equal performance with other well documented studies of commercial growth promoters probiotic $\left(\right.$ Biogen $\left.^{\circledR}\right)$ and prebiotic $\left(\right.$ Garlin Plus $\left.{ }^{\circledR}\right)$.

The present results were in agreement with the results obtained by many authors. Ali et al., 2010; Agouz and Anwer (2011) pointed out to the improvement of digestion and metabolism in the fish body due to the presence of the bacillus in the probiotic $\left(\right.$ Biogen $\left.{ }^{\circledR}\right)$, moreover the prevention of pathogenic bacteria colonies in fish gut. Renuka et al. (2013) suggested that the incorporation of probiotic in common carp diets stimulated fish growth and digestion as micro biota colonization enzymes that hydrolyze complex molecules, facilitate better digestion and absorption of macronucleus resulting in higher protein and energy deposition in the body tissues. In these aspects, Faramarziet al.,(2011) was in accordance with the results obtained in the present work, where they found that the addition of probiotics (Bacillus subtilis c-3102 spores) in Common carp fry diets improved fish growth and mitigated the effects of stress factors. In this particular, diets supplemented mix of Lactobacillus SP. spores resulted in improving growth performance of Striped mullet (Mugil cephalus) significantly than those fed the control basal diets (El-Tawil et al., 2012) 
Mohapatra et al. (2012) who found that incorporation of live probiotic microorganisms (Lactobacilis lactis and Bacillus subtilus) resulted in maximum growth performance in rohu (Labeo rohita) fingerlings in comparison with some combinations of inactivated probiotics.

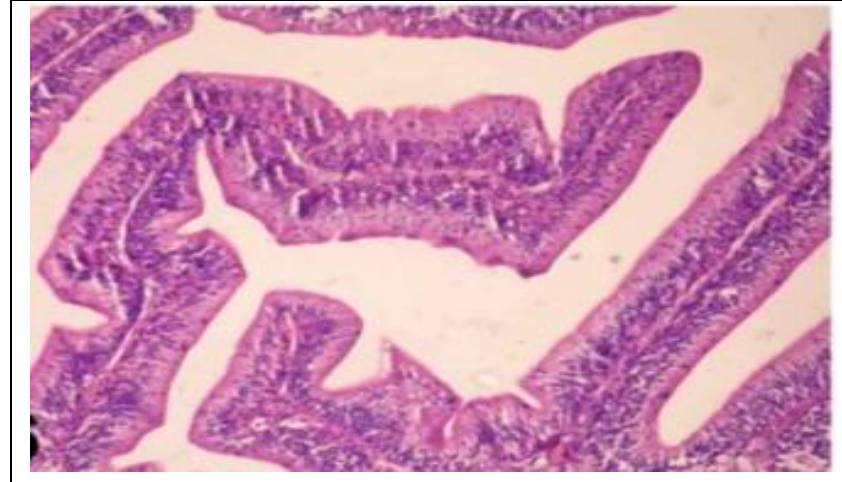

Fig. (5) Intestine of fish treated with probiotic showing increase in length of villus height. H\&EX200

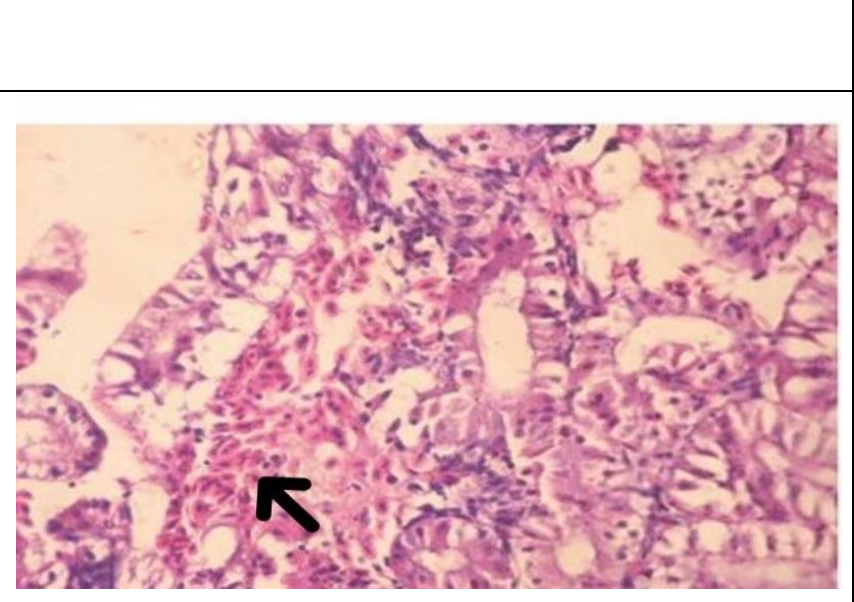

Fig. (7) Kidney of fish treated with $0.03 \%$ of Spirulina showing hemorrhagic area in interstitial tissues. H\&EX 200.

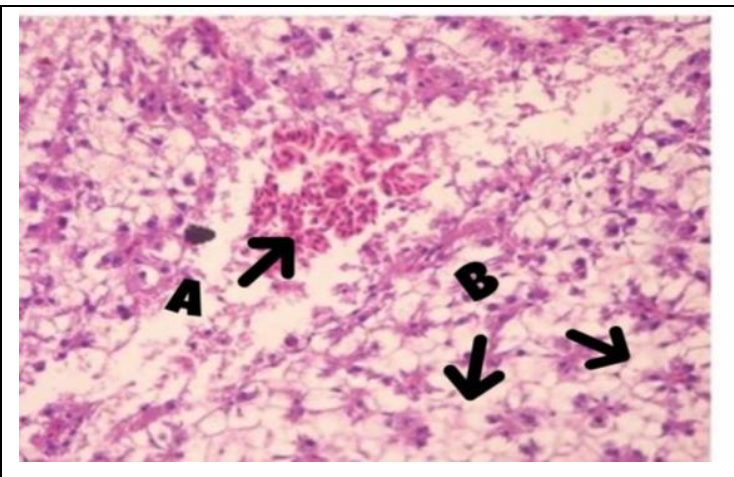

Fig. (6)Liver of fish treated with $0.03 \%$ of Spirulina showing (A) focal hemorrhagic areas dispersed the hepatocytes and (B) individual necrosis of hepatocytes. H\&EX 200.

Other similar results were also observed for Nile tilapia (Lara-Flores et al., 2003), Cyprinus carpio (Ramakrishnan et al., 2008) they found that the incorporation of Spirulina and probiotics in Common carp diets improves growth performance and total heterotrophic microbial load. The Spirulina diets were most effective in stimulating fish growth. Additionally, the fish fed diet supplemented with prebiotic showed improvement it was suggested that the improvement in growth parameters occurred with the prebiotic diets may be due to the fermentation of prebiotics in colon which promote the growth of the bacterial populations associated with the healthy well-functioning colon. Beneficial types of colonic bacteria have the ability of oligosaccharides fermentation which is not used effectively by potentially pathogenic bacteria species (Yosefian and Amiri 2009). As in the case of probiotics, the positive effect of prebiotics on growth was also found in different fish species such as Atlantic salmon, (Refstie et al., 2006) ,Rainbow trout (Grisdale-Hellandetal.,2008) Rainbow trout, Hybrid tilapia (Genc and Yilmaz 2007 Yilmaz et al., 2007) .

From all pervious discussion and go parallel with the scope of Silva -Nato et al. (2012) It would be possible to achieve better growth performance results if higher levels of Spirulina had been used in the present work . But, it was not our purpose to test Spirulina as a source of macronutrients, such as amino acids or fatty acids or even as protein source in fish diets. Our aim was to test Spirulina as a feed additive (growth promoter), included at very low dietary levels. This question needs to be heighted because the price of Spirulina is very high making its use not economically feasible to high dietary inclusion levels. 


\section{CONCLUSION}

Despite the green water contained natural cyanobacteria, the inclusion of spray dried Spirulina at $0.03 \%$ in Nile tilapia diet improved growth performance, feed utilization and crude protein content under field conditions. At lab scale, it may have a positive effect on gut condition similar to probiotics and prebiotics.

\section{ACKNOWLEDGEMENT}

Authors would like to express our appreciation to Professor Mohamed Saad Ali professor of Microbiology in National Research Centre who give us the Spirulina powder from Germany and his support during the course of the experiment and Dr Mohamed said lecturer of Aquaculture Department, Faculty of Fish Resources, Suez University, Egypt for kind help in reviewed manuscript drafts.

\section{REFERENCES}

Abdel-Tawwab, M. and M.H. Ahmed (2009). Live Spirulina (Arthrospira platensis) as a growth and immunity promoter for Nile tilapia, Oreochromis niloticus (L.), challenged with pathogenic Aeromonas hydrophila. Aquaculture Research, 40: 1037- 1046.

Ali, H.M.; A.A. Ghazala; E.A.Gehad; Y.A. Hammouda and H.A. Abo-State (2010). Practical aspects and immune response of probiotics preparations supplemented to Nile tilapia $(O . n)$ diets. Nature and Science, 8(5): 39-45.

AOAC. (2006). Official Methods of Analysis, $18^{\text {th }}$ ed. Association of Official Analytical Chemists, Arlington, VA, USA.

APHA (1999). Standard methods for the examination of water and wastewater. American Public Health Association. Washington, D.C.

Agouz, H.M. and W. Anwer (2011). Effect of Biogen ${ }^{\circledR}$ and Myco-Ad ${ }^{\circledR}$ on the growth performance of Common carp (Cyprinus carpio) fed a mycotoxin contaminated Aqua feed .Journal of Fisheries and Aquatic Science, 6 (3): 334-345.

Bancroft, J.D.; A. Stevens and D.R. Turner (1996). Theory and Practice of Histological Techniques. ${ }^{\text {th }}$ Ed., Churchill, Livingston, New York.

Deng, R. and T.J. Chow (2010). Hypolipidemic, antioxidant, and anti-inflammatory activities of microalgae Spirulina. Cardiovascular Therapeutics, 28, 33-45.

Duncan, D. (1955). Multiple range tests and multiple F tests. Biometrics, 11: 1-42.

Ekpo, I. and J. Bender (1989). Digestibility of a commercial fish feed, wet algae, and dried algae by Tilapia nilotica and silver carp. The Progressive Fish-Culturist, 51: 83-86.

El-Tawil, N.E.; T.N. Amer; M.H. Ahmed and M.E. Seden (2012). Effect of different levels of probiotic (Lactobacillus sp.,) on fish performance, survival and feed efficiency of striped mullet Mugil cephalus fed on all plant diet. Egyptian Journal of Nutrition and Feeds, 15(1):193-202.

El-Sayed, A.F.M. (2006). Tilapia Culture. CABI publishing, CABI International, Willing ford, Oxford shire, UK, pp. 274.

Faramarzi, M.;S. Kiaalvandi and F. Iranshahi (2011). The effect of probiotics on growth performance and body composition of Common carp (Cyprinus carpio). Journal of Animal and Veterinary Advances, v. 10, n. 18, p. 24

Food and Agriculture Organization (FAO) (2014). Global Aquaculture Production 1950-2012. FAO, Rome, Italy (http://www.fao.org/fishery/statistics/global-aquaculture- production/en).

Food and Agriculture Organization (FAO) (2016). The State of World Fisheries and Aquaculture 2016.Contributing to food security and nutrition for all. Food and Agricultural Organization, Rome, Italy. 


\section{Abo-State et al.}

Genc, E. and E. Yilmaz (2007). Effects of dietary mannan oligosaccharides (MOS) on growth, body composition and hepatopancreas histology of Penaeus semisulcatus (de Haan 1844). Aquaculture Nutrition, 13: 156-161.

Grisdale-Helland, B. ; S. J. Helland and D. M. Gatlin (2008).The effect dietary supplementation with mannanoligosacchride, fructoosaccharideorgalactooligosaccharide on the growth and utilization of Atlantic salmon (Salmon salar). Aquaculture,283(1-4):163-167.

Hirahashi, T.; M. Matsumoto; K. Hazeki; Y. Saeki; M. Ui and T. Seya (2002). Activation of the human innate immune system by Spirulina: augmentation of interferon production and NK cytotoxicity by oral administration of hot water extract of Spirulina platensis. International Immuno pharmacology, 2: $423-434$.

Holman, B.W.B. and A.E.O. Malau-Aduli (2013). Spirulina as a livestock supplement and animal feed. Journal of animal Physiology and Animal Nutrition, 97(4): 615-623.

Horn, M.H. and K.S. Messer (1992) Fish guts as chemical reactors:a model of the alimentary canals of marine herbivorous fishes Marine Biology, 113: 527-535.

Ibrahim, M.D. and M.A. Ibrahim (2014). The potential effects of Spirulina platensis (Arthrospira platensis) on tissue protection of Nile tilapia (Oreochromis niloticus) through estimation of p53 level. Journal of Advanced Research, 5,133-136.

Jaime-Ceballos, B.J., A. Hernández-Llamas, T. Garcia-Galano and H. Villarreal (2006). Substitution of Chaetocerosmuelleri by Spirulina platensis meal in diets for Litopenaeus schmitti larvae. Aquaculture 260, 215-220.

Kamilya, D.; S. Sarkar; T.K. Maiti; S. Bandyopadhyay and B.C. Mal (2006). Growth and nutrient removal rates of Spirulina platensis and Nostocmus corumin fish culture effluent: a laboratory-scale study. Aquaculture Research, 37: 1594- 1597.

Lara- Flores, M.; M.A. Olvera - Novoa; B.E. Guzmán - Méndez and W. López-Madrid (2003). Use of the bacteria Streptococcus faecium and Lactobacillus acidophilus, and the yeast Saccharomyces cerevisiae as growth promoters in Nile tilapia (Oreochromis niloticus).Aquaculture, 216: 193-201.

Lin, L.P. (1985). Microstructure of spray-dried and freeze-dried microalgal powders. Food microstructure, 4: 341-348.

Mohapatra,S.;T.C.hakraborty;A.K. Prusty; P. Das; K. Paniprasad and K.N. Mohanta (2012).Use of different microbial probiotics in the diet of rohu, Labeo rohita fingerlings: effects on growth, nutrient digestibility and retention, digestive enzyme activities and intestinal microflora. Aquaculture Nutrition, 18(1):1-11.

Nandeesha,M.C.; B. Gangadhar; T.J. Varghese and P. Keshavanath (1998). Effect of feeding Spirulina platensis on the growth, proximate composition and organoleptic quality of Common carp, Cyprinus carpio L. Aquaculture Research. 29. 305- 312.

Ramakrishnan, C.M.; M.A., Haniffa; M. Manohar J.M. Dhanara; A. JesuArockiaraj; S.Seetharaman and S.V. Arunsingh (2008). Effects of probiotics and spirulina on survival and growth of juvenile Common carp Cyprinus carpio.IsraliJournal of Aquaculture. Bamidgeh, 60:128-133.

Refstie, S.; T. Landsverk; A.M. Bakke-McKellep; E. Ring $\varnothing ;$ A. Sundby; K.D. Shearer and A. Krogdahl (2006). Digestive capacity, intestinal morphology, and microflora of 1-year and 2-year old Atlantic cod (Gadus morhua) fed standard or bioprocessed soybean meal. Aquaculture,261:269-284.

Regunathan, C. and S.G. Wesley (2006). Pigment deficiency correction in shrimp brood stock using spirulina as a carotenoid source. Aquaculture Nutrition, 12: 425- 432.

Renuka, K.P.; M. Venkateshwarlu; A.T. Ramachandra Naik and S.M. Prashantha Kumara (2013). Influence of probiotics on growth performance and digestive enzyme activity of Common carp Cyprinus carpio, International Journal of Current Research,5(7):1696-1700.

Sarker, P.K.; M.R. Gamble; S. Kelson and A.R. Kapuscinski (2016). Nile tilapia (Oreochromis niloticus) show high digestability of lipid and fatty acids from marine Schizochytrium sp. and of protein and essential amino acids from freshwater Spirulina sp. feed ingredients. Aquaculture Nutrition,22: 109119 . 
Silva- Neto, J.F.; A.J. Pinto Nunes; H. Sabry- Neto and S.A. Carmo (2012). Spirulina meal has acted as a strong feeding attractant for Litopenacus vannamei at a very low dietary inclusion level. Aquaculture Research, 43(3) 43: 430- 437.

SPSS (2007). Statistical Package for Social Science (for Windows).Release 16 copyright, SPSS Inc., Chicago, USA.

Sultana, N.; P. Nour; A.T. Abdullah; M.R. Hasan; K.M. Ahmed and M.N. Naser (2012). Growth performance and nutrient composition of Juvenile Nile tilapia (Oreochromis niloticus) fed Spirulina flakes, rice bran and mustard oil cake. Malaysa Journal of Nutrition 18 (2): 275-282.

Tahoun, A.M.A. (2007): Studies on some factors affecting the production and reproduction of Nile tilapia (Doctoral dissertation, Ph. D. Thesis, University of Kafr El-sheikh, Egypt.

Teimouri M.; A.K. Amirokolaie and S. Yeganeh (2013a). The effects of Spirulina platensis meal as a feed supplement on growth performance and pigmentation of rainbow trout (Oncorhynchus mykiss).Aquaculture. 396- 399: 14- 19.

Teimouri M.; A.K. Amirkolaie and S. Yeganeh (2013b). The effects of dietary supplement of Spirulina platensis on blood carotenoid concentration and fillet color stability in rainbow trout (Oncorhynchus mykiss). Aquaculture. (414- 415): 224- 228.

Yilmaz, E.; M. A. Genc and E. Genc, 2007. Effects of dietary mannan oligosaccharides on growth, body composition, and intestine and liver histology of rainbow trout, (Oncorhynchus mykiss). Israli Journal of Aquaculture .Bamidgeh, 59: 182-188.

Yousefian, M. and M.S. Amiri, 2009. A review of the use of prebiotics in aquaculture for fish and shrimp. African Journal of Biotechnology, 8:7313-7318.

\section{استخدام طحلب الاسبيريولينا المجفف بطريقة الرش كمحن نمو لاسماك البلطى النيلى تحت الظروف المعملية
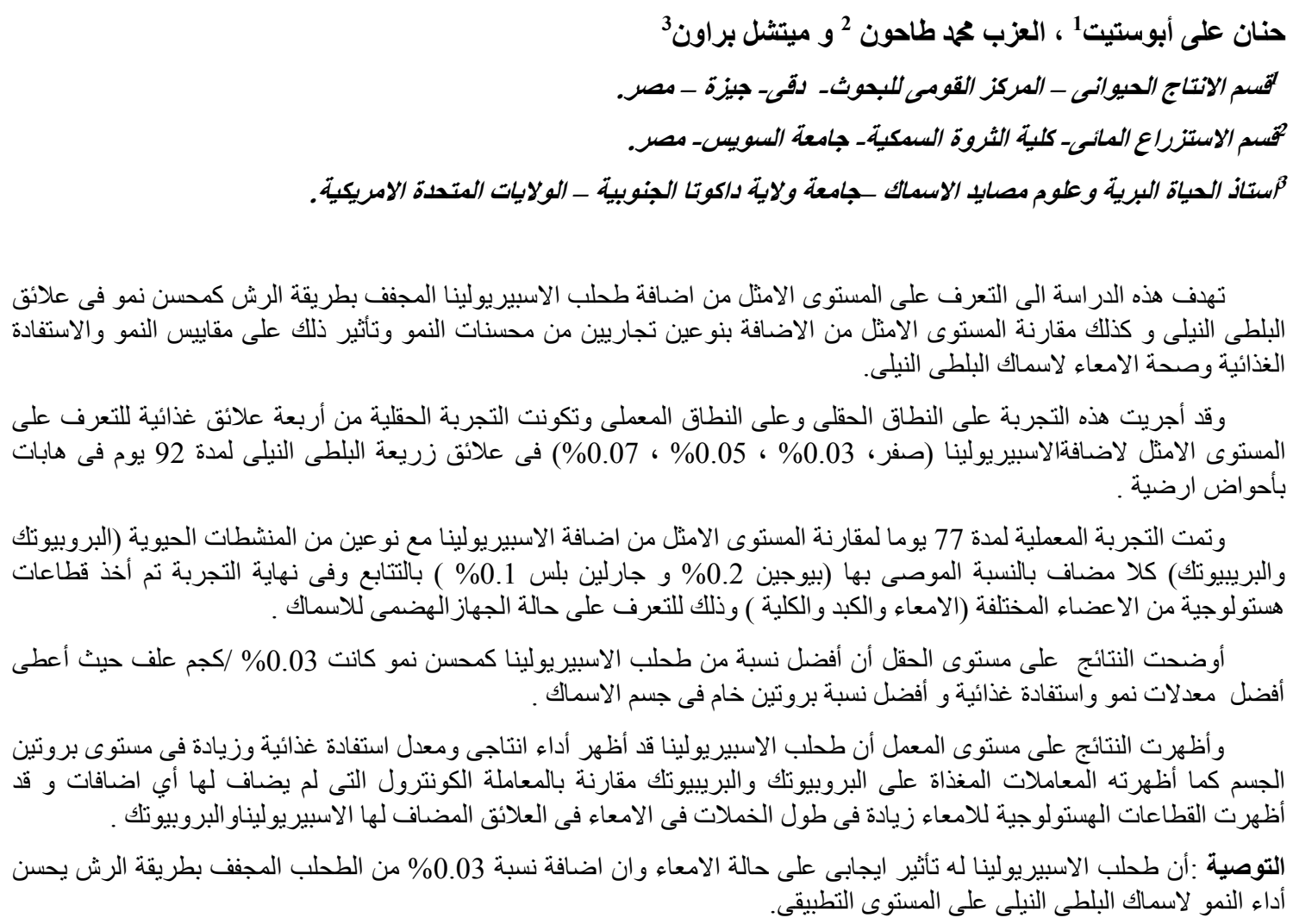